\title{
Gifted discoverer of the neutron
}

\section{The Neutron and the Bomb: $A$} Biography of Sir James Chadwick by Andrew Brown

Oxford University Press: 1997. Pp. 366. $£ 29.50, \$ 55$

\section{Brian Pippard}

James Chadwick (1891-1974) was taciturn and little given to those merry quips, outbreaks of rage or peccadilloes that can enliven a biography. The tale of so sterling a character, even when told as well as in this book, may be a little short on light moments, but any reader interested in the evolution of physics from an academic passion to a leading role on the world stage will find it a fascinating story and a worthy tribute to a great scientist.

Chadwick was nearly 48 when war broke out in 1939, at the height of his career and fully engaged in the construction of a cyclotron at the University of Liverpool, which was to be the most ambitious European venture in nuclear physics. Britain was then the leader in the first steps towards a nuclear bomb to counter the assumed parallel effort in Germany. The later decision by the United States to join the race, with far greater resources, provided much scope for jealousy on both sides, arousing real fear that only US citizens would be allowed to take part. It was Chadwick's mission to avert narrow-minded decisions that would have damaged both nations. It brought out in him a skill at diplomacy that few would have predicted, and in three years of unremitting toil tested, almost to the limit, his none-too-robust frame. He travelled to Los Alamos, New Mexico, in the middle of the war to work on the Manhattan Project.

General Leslie Groves, in overall charge of American nuclear bomb development, was a very different sort of man - large, blunt and autocratic, and utterly confident in his own judgement: qualities indispensable for success in the huge project. He quickly appreciated Chadwick's intellectual strength and personal integrity, as he had also recognized J. Robert Oppenheimer's high qualities, both men with characters foreign to his own. Chadwick and Groves found they could talk freely together, and their friendship helped to overcome the American desire to go it alone, which was by no means irrational in view of the genuine fear that security would be jeopardized by European involvement.

It was, of course, no accident that Chadwick was chosen to represent British interests. He was already deeply engaged in the problems generated by the discovery of nuclear fission, and the first half of the book is concerned with his rise to a dominant position in nuclear physics from a very humble start. Little would be known of his early life if he had not talked freely in 1964 to Charles Weiner, who must have charmed him into uncharacteristic garrulity, even to speaking of the boyhood home on which he was usually silent. A scholarship took him to the University of Manchester, where he would have read mathematics but for the mistake of going to the physics lecturer for an interview and having his original intention subverted. Thus, in due course, he came under Ernest Rutherford's influence, which lasted until the great man's death in 1938.

Chadwick graduated and started research in Manchester. He won a scholarship from the Royal Commission for the Exhibition of 1851, only to learn that the commissioners insisted he hold it elsewhere. So in 1913 he went to Berlin for a year with Rutherford's old associate Hans Geiger; and in Germany he stayed, interned at Ruhleben as an enemy alien after war broke out, until November 1918. Life was hard, and his subsequent prolonged periods of ill-health may have started there. But the prisoners were resourceful, and organized educational courses and even small-scale researches with the help of friends among the German scientists. One of the group, a Woolwich cadet named Charles Ellis who had been caught on holiday, learnt about physics from Chadwick and on release went to Cambridge as a student, eventually joining Chadwick as a member of Rutherford's Cavendish Laboratory staff.

In 1918 Rutherford was still at Manchester and Chadwick returned to him there, but accompanied him in his move to Cambridge the following year. From then until 1935 he was Rutherford's right-hand man, calmly efficient in the administrative tasks that only irritated the professor, and at the same time taking a lead in the nuclear research that was the principal activity of the Cavendish as well as seeing to the needs of the ever-growing population of research students.

IMAGE

UNAVAILABLE FOR From the early 1920s, RutherCOPYRIGHT REASONS ford had hoped to find evidence for a close association of the proton and electron which would act as a neutral component of nuclear structure, and in 1932 Chadwick made the actual discovery of the neutron which won him the

Chadwick: great scientist - and a diplomat.
Nobel prize in 1935. By now the Cavendish was leading the world in nuclear physics, with an almost exclusively experimental approach that had been established by Rutherford but was very much to Chadwick's taste. Their experiments were economical in conception and their papers were notable for clear exposition and, as far as possible, avoidance of mathematical arguments - merits for which the author of this book must have been thankful. Chadwick's researches can be described without technical complication and still give a fair picture of what was achieved.

Despite Chadwick's preference for working alone with simple bench-top apparatus, Ernest Lawrence's invention of the cyclotron, and the consequent birth in America of a new style of nuclear physics with unprecedentedly massive and expensive equipment, persuaded him that Britain must follow suit or fall behind. Rutherford would have none of it, and his forthright rejection of Chadwick's proposals made a break almost inevitable. Chadwick went off to the chair at Liverpool and set about realizing his ambitions in a seriously run-down department. In the four years before the outbreak of war he had achieved much, and the cyclotron was just about working, but he had pressing calls on his time and never published any original work with it, leaving everything to his junior staff.

In fact, his career in academic research was over. By the end of the war, when he returned to Liverpool, he was exhausted and out of touch with the finicky details of university life under straitened conditions. Perhaps it was the hopes of rediscovering his lost Utopia that persuaded him to accept the mastership of Gonville and Caius College in 1948; but whatever the initial pleasures of a return to Cambridge, they were transient. Disagreements with the younger, and sometimes intolerant, fellows became more than he could bear, and at the end of 1958 he resigned. In those ten years he had not renewed contact with the Cavendish, and his departure from Cambridge was hardly noticed outside the college that had failed to appreciate his great gifts or to match his old-fashioned standards of civility.

Andrew Brown is a radiation oncologist and presumably not a stranger to nuclear physics. He has made a few slips in matters of detail which experts will correct without trouble and which are without consequence in the argument. He has made good use of what seem to be all the available archives except for a few still classified as secret. There is already a substantial collection of biographies of modern physicists, and this book is a fine addition to their number

Sir Brian Pippard is at the Cavendish Laboratory, Madingley Road, Cambridge CB3 OHE, UK. 